\title{
y4xP, an Open Reading Frame Located in a Type III Protein Secretion System Locus of Sinorhizobium fredii USDA257 and USDA191, Encodes Cysteine Synthase
}

\author{
Julio C. Lorio, ${ }^{1}$ Demosthenis Chronis, ${ }^{2}$ and Hari B. Krishnan ${ }^{2,3}$ \\ ${ }^{1}$ Department of Plant Microbiology and Pathology, ${ }^{2}$ Department of Agronomy and ${ }^{3}$ Plant Genetics Research Unit, United \\ States Department of Agriculture-Agricultural Research Service, University of Missouri, Columbia, MO 65211, U.S.A.
}

Submitted 2 November 2005. Accepted 1 February 2006.

\begin{abstract}
Sinorhizobium fredii USDA257, a soybean symbiont, exports several nodulation outer proteins (Nops) into the rhizosphere. These proteins, which are exported by a type III secretion system (TTSS), have a pivotal role in host-specific nodulation. The entire TTSS of $S$. fredii lies within a 31-kb region that includes conserved genes that code for secretion machinery proteins, Nops, and several open reading frames (ORF) of unknown function. Identifying the functions of these ORF is essential to understand fully the role of TTSS in nodulation. Here, we report the characterization of $y 4 x P$, an ORF of previously unknown function. Southern blot analysis revealed that USDA257 contains two copies of $\mathbf{y} 4 \mathbf{x P}$, while a sibling, USDA191, contains a single copy. The amino acid sequence of Y4XP is homologous to both eukaryotic and prokaryotic cysteine synthase, a key enzyme in sulfur assimilation. The coding region of USDA257 y4xP under control of $\mathrm{T} 7$ promoter was expressed in Escherichia coli, and the recombinant protein was purified by nickel-affinity chromatography. Antibodies generated against soybean cysteine synthase cross-reacted with the recombinant protein. A nonpolar mutant of $\mathbf{y} 4 \mathrm{xP}$ of USDA191 showed a marked reduction in cysteine synthase activity. Enzyme activity was completely restored when the mutant was complemented with a plasmid containing the $\mathbf{y} 4 \times \mathbf{P}$ sequence. Cysteine synthase activity was confined to the cell cytosol. Extracellular protein fraction from genistein-induced USDA191 showed no cysteine synthase activity. This observation indicates that cysteine synthase, which is located in the TTSS locus, is not a type III secreted protein. A nonpolar cysteine synthase mutant was able to export all the Nops to the rhizosphere, albeit in reduced amounts compared with the wild-type USDA191. Interestingly, USDA191 cysteine synthase mutant was able to initiate nodules on 'McCall' soybean more efficiently than the wild-type. Our results demonstrate that $\mathrm{y} 4 \mathrm{xP}$ encodes a cysteine synthase and inactivation of this gene enhances the ability of USDA191 to form nodules on 'McCall' soybean by regulating Nops production.
\end{abstract}

\section{J. C. Lorio and D. Chronis contributed equally to this work.}

Corresponding author: H. B. Krishnan; E-mail: KrishnanH@missouri.edu; Telephone: +1.573.882.8151; Fax: +1.573.884.7850.

This article is in the public domain and not copyrightable. It may be freely reprinted with customary crediting of the source. The American Phytopathological Society, 2006.
Soil bacteria belonging to the genera Allorhizobium, Azorhizobium, Rhizobium, Bradyrhizobium, Mesorhizobium, and Sinorhizobium, collectively known as rhizobia, have the unique ability to form specialized structures called nodules on compatible legume roots or stems. Nodulation is a highly selective process in which symbiotic partners recognize each other through exchange of molecular signals (Broughton et al. 2000; Dénarié et al. 1993). Legume roots secrete a variety of chemical compounds, mostly flavonoids, that interact with NodD protein, a member of the LysR family of transcriptional regulators (Schlaman et al. 1992). NodD acts as a transcriptional activator of both "common" and "host-specific" nod genes that direct the synthesis and secretion of lipochitooligosaccharide signal molecules called Nod factors (Dénarié et al. 1996; Long 1996). These are oligomers of $\beta$-1,4-linked $N$-acetylglucosamine residues carrying specific modifications at the reducing and nonreducing ends (Dénarié et al. 1996; Long 1996). Nod factors initiate several initial events of symbiosis, including root-hair deformation, entry of the bacteria into the root hairs, and cortical cell division (Dénarié et al. 1996). Bacteria are delivered to the cortical cells by the infection threads and cause cell division and enlargement of the nodule primordia. Once inside the nodules, rhizobia differentiate into bacterioids, structures that are capable of reducing diatomic atmospheric nitrogen to ammonia (Lodwig et al. 2003; Patriarca et al. 2002).

Sinorhizobium fredii USDA257, primarily known as a soybean symbiont, forms nitrogen-fixing nodules on diverse legumes (Pueppke and Broughton 1999). In spite of its broad host-specificity, this strain exhibits cultivar-specific nodulation with respect to soybean (Keyser et al. 1982). USDA257 initiates nitrogen-fixing nodules on primitive soybean cultivars but fails to nodulate agronomically improved North American cultivars such as 'McCall' (Annapurna and Krishnan 2003; Heron and Pueppke 1984; Heron et al. 1989). The inability of USDA257 to nodulate 'McCall' soybean is regulated by the nolWXBTUV locus which is located on a sym plasmid (Meinhardt et al. 1993). Mutations in any of these genes enable $S$. fredii USDA257 to nodulate 'McCall'. Subsequent characterization of this locus has revealed it to be an integral part of a type III secretion system (TTSS). TTSS, which have been well characterized in animal and plant pathogenic bacteria, are utilized to deliver effector proteins to eukaryotic cells. The TTSS of USDA257 is contained in a 31$\mathrm{kb}$ sym plasmid DNA region and includes rhc (rhizobia-conserved) genes that encode components of secretion machin- 
ery and nodulation outer proteins (Nops). The genomic organization of the TTSS of USDA257 is remarkably similar to another broad-host range soil bacterium, Rhizobium sp. strain NGR234 (Krishnan et al. 2003; Marie et al. 2001). In both USDA257 and NGR234, inactivation of the different components of the TTSS significantly influences the ability of these two rhizobia to nodulate legumes in a host-dependent manner (Krishnan et al. 2003; Marie et al. 2001). In addition to Nops, the TTSS of USDA257 contains several open reading frames (ORF) of unknown function (Krishnan et al. 2003). To fully understand the role of TTSS in symbiosis, it is essential to identify these ORF and elucidate their functions. In the present investigation, we have focused our attention on $\mathrm{y} 4 \mathrm{xP}$, an ORF located between two Nops-encoding genes, nopX and nopP. Our results demonstrate $\mathrm{y} 4 \mathrm{xP}$ encodes cysteine synthase, a pivotal enzyme in sulfur assimilation. USDA257 contains two copies of $\mathrm{y} 4 \mathrm{xP}$, while USDA191, a sibling of USDA257 has a single copy. Inactivation of USDA191, y4xP drastically reduced the cysteine synthase activity, reduced Nops production, and enhanced the ability of this mutant to nodulate 'McCall' soybean.

\section{RESULTS}

\section{S. fredii USDA257 contains two copies of $\mathrm{y} 4 \mathrm{xP}$.}

Sequence analysis of the soybean cultivar specificity locus of USDA257 has revealed the presence of $\mathrm{y} 4 \mathrm{yB}, \mathrm{y} 4 \mathrm{yA}, \mathrm{y} 4 \mathrm{xP}$, $\mathrm{y} 4 \mathrm{xO}, \mathrm{y} 4 \mathrm{xN}$, and $\mathrm{y} 4 \mathrm{xM}$ located in the midst of a functional type III protein secretion system (Krishnan et al. 2003). These ORF are located between nopX and nopL, two genes that encode proteins secreted by TTSS (Fig. 1). Transcriptional analysis revealed that $n o p X, \mathrm{y} 4 \mathrm{yB}, \mathrm{y} 4 \mathrm{yA}, \mathrm{y} 4 \mathrm{xP}, \mathrm{y} 4 \mathrm{xO}, \mathrm{y} 4 \mathrm{xN}$, and y4xM may form a single transcriptional unit (Perret et al. 1999). Earlier, we demonstrated that USDA257 contains two copies of $\mathrm{y} 4 \mathrm{yB}$ and $\mathrm{y} 4 \mathrm{yA}$, one located on the sym plasmid and the other on the chromosome (Jiang and Krishnan 2000). The chromosomal copies are identified by a superscript $\mathrm{c}\left(\mathrm{y} 4 \mathrm{yB} \mathrm{B}^{\mathrm{c}}\right.$ and $\mathrm{y}^{4} \mathrm{yA}^{\mathrm{c}}$ ). However, USDA191, a sibling of USDA257 carries a single copy of $\mathrm{y} 4 \mathrm{yB}$ and $\mathrm{y} 4 \mathrm{yA}$ on the sym plasmid. The USDA257 chromosomal copy of the $\mathrm{y} \mathrm{yB}^{\mathrm{c}}$ and $\mathrm{y} \mathrm{yA}^{\mathrm{c}}$ was located in a 4.0-kB EcoRI fragment (Jiang and Krishnan 2000). We now have sequenced the DNA region immediately following $\mathrm{y} 4 \mathrm{yA}^{\mathrm{c}}$ and have identified the presence of $\mathrm{y}^{4} \mathrm{xP}^{\mathrm{c}}$ and

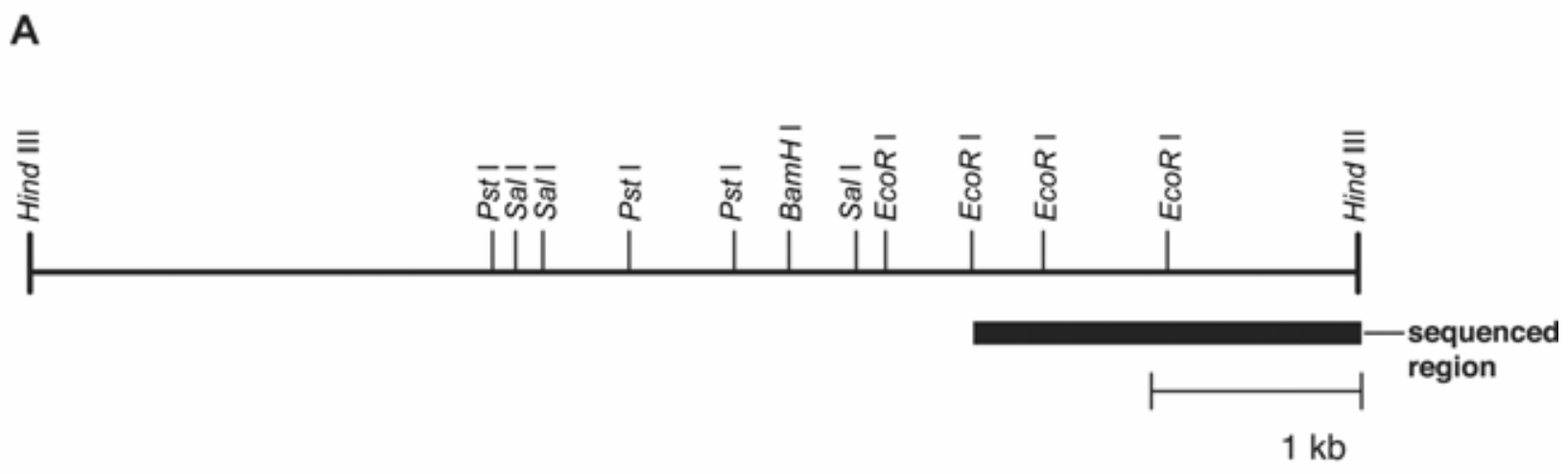

B
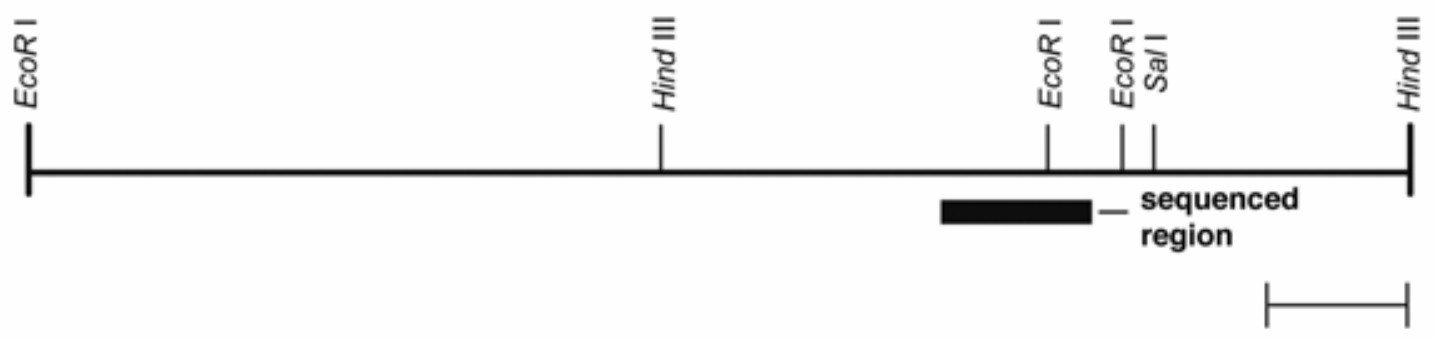

$1 \mathrm{~kb}$

C

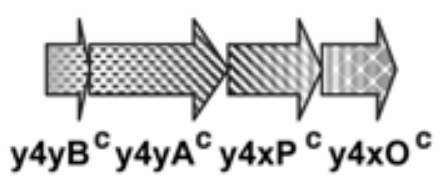

D

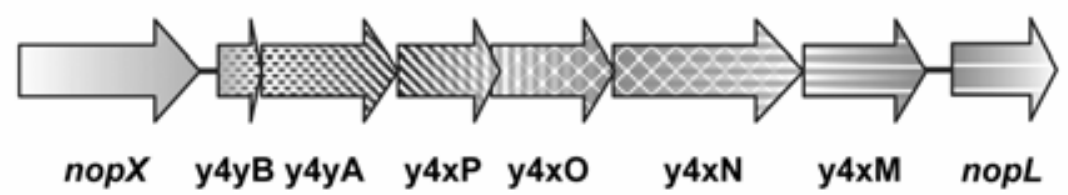

Fig. 1. Physical map of restriction endonuclease sites in the DNA region containing the $y 4 x P^{c}$ of A, Sinorhizobium fredii USDA257 and B, USDA191. The superscript " $\mathrm{c}$ " refers to the chromosomal copy. The thick lines indicate the sequenced regions. C, Physical organization of y4xP located in the chromosome and on D, sym plasmid. Note the plasmid copy of y4xP is located in the type III secretion system locus of USDA257 and USDA191. 
$\mathrm{y} 4 \mathrm{xO}^{\mathrm{c}}$, which have the same orientation as the plasmid copy (Fig. 1). Southern hybridization analysis with HindIII and SalI-digested genomic DNA from USDA257 and USDA191 showed strong hybridization signals when probed with the polymerase chain reaction (PCR)-amplified ${ }^{32} \mathrm{P}$-labeled coding region of $\mathrm{y} 4 \mathrm{xP}$. In the case of USDA257, two hybridization bands were detected, while only a single band was found in USDA191 (Fig. 2).

\section{y4xP shows sequence homology \\ to both prokaryotic and eukaryotic cysteine synthase.}

A comparison of $\mathrm{y} 4 \mathrm{xP}$-deduced amino acid sequences of chromosomal $\left(\mathrm{y}^{4} \mathrm{xP}^{\mathrm{c}}\right)$ and plasmid copies revealed that they are $94 \%$ identical. Similarly, the USDA191 y4xP $\mathrm{xP}^{\mathrm{c}}$ sequence was found to be highly homologous to the USDA257 sequences. Each of these genes encodes a $35-\mathrm{kDa}$ protein with an isoelectric point of 5.9. A BLAST search against the SWISSPROT database showed that Y4XP shared significant homology to cysteine synthases from prokaryotes including, Escherichia coli, Rhizobium sp. strain NGR234, Mesorhizobium loti, Erwinia carotovora, Synechocystis spp., and Nostoc spp., and eukaryotes, Glycine max, Arabidopsis thaliana, and Solanum tuberosum. Cysteine synthase is a pyridoxal phosphate-dependent enzyme and contains a conserved lysine residue at the active site (Fig. 3). Both USDA257 and USDA191 Y4XP have this conserved lysine residue near the $\mathrm{N}$-terminal region (Fig. 3 ). A comparison of the amino acid sequence shows that the residues that interact with pyridoxal phosphate and the substrate are conserved in both prokaryotes and eukaryotes (Fig. 3).

\section{Recombinant Y4XP shows antigenic homology}

\section{to soybean cysteine synthase.}

To demonstrate that Y4XP has cysteine synthase activity, we first purified this protein. An ample supply of the protein was obtained by cloning the coding region of the USDA257 $\mathrm{y} 4 \mathrm{xP}$ plasmid copy into $E$. coli protein expression vector pET28a. The bacterial culture grown overnight in the presence of isopropyl-beta-D-thiogalactoside (IPTG) produced a recombinant $45-\mathrm{kDa}$ protein that was absent in noninduced cultures (Fig. $4 \mathrm{~A})$. The size of the recombinant protein is slightly larger than the size of the protein deduced from the $\mathrm{y} 4 \mathrm{xP}$ nucleotide sequence. The reason for this aberrant migration of the recombinant Y4XP on sodium dodecyl sulfate-polyacrylamide gel electrophoresis (SDS-PAGE) is not clear. Since the recombinant protein contains six-histidine residues at the $\mathrm{C}$-terminus of Y4XP, we were able to purify this protein using nickelaffinity column chromatography under denaturing conditions (Fig. 4). However, our repeated attempts to purify the recombinant Y4XP under nondenaturing conditions were not successful because we were unable to solubilize Y4XP, which was found exclusively in inclusion bodies. Expression of the USDA257 chromosomal copy of $\mathrm{y}^{\mathrm{xP}} \mathrm{P}^{\mathrm{c}}$ also resulted in insoluble recombinant protein. Earlier, we had raised antibodies against soybean cysteine synthase (Chronis and Krishnan 2003). Western blot analysis using soybean cysteine synthase antibodies revealed strong cross-reactivity against the recombinant Y4XP (Fig. 4B) indicating that this protein has antigenic homology to the soybean cysteine synthase.

\section{A nonpolar $\triangle \mathrm{y} 4 \mathrm{xP}$ deletion mutant has}

drastically reduced cysteine synthase activity.

To obtain biochemical evidence that $\mathrm{y} 4 \mathrm{xP}$ encodes for cysteine synthase, we created nonpolar $\mathrm{y} 4 \mathrm{xP}$ deletion mutants. The coding region of $\mathrm{y} 4 \mathrm{xP}$ in both USDA257 and USDA191 plasmid copies were precisely excised and replaced by the $n p t I I$ cassette. A comparison of cysteine synthase activity between these mutants and wild-type parents are shown in Figure
5. Cysteine synthase was barely detected in the USDA191 $\triangle \mathrm{y} 4 \mathrm{xP}$ mutant, while the USDA257 $\Delta \mathrm{y} 4 \mathrm{xP}$ mutant showed only a minimal reduction in enzyme activity. The difference in cysteine synthase activity between these two rhizobia could be explained by the fact that USDA191 has a single copy of $\mathrm{y} 4 \mathrm{xP}$ while USDA257 has two copies (Fig. 1). Even though USDA257 contains two copies of $y 4 x P$, the cysteine synthase activity in USDA191 was three times greater than that of USDA257. When a plasmid copy of $\mathrm{y} 4 \mathrm{xP}$ was introduced into the $\triangle \mathrm{y} 4 \mathrm{xP}$ deletion mutants, cysteine synthase activity was completely restored and the levels were higher than in the wild type (Fig. 5).

\section{Genistein induces the transcription of $y 4 x P$.}

Earlier, we demonstrated that the transcription of nopX is inducible by flavonoids (Bellato et al. 1997; Meinhardt et al. 1993). A 185-bp intergenic region separates nopX and y4xP. We cloned this region in the promoter probe vector pMP220 and found no evidence for promoter activity in this region. This suggests that the $\mathrm{y} 4 \mathrm{xP}$ could be a part of a single transcriptional unit encompassing $n o p X, \mathrm{y} 4 \mathrm{yB}, \mathrm{y} 4 \mathrm{yA}, \mathrm{y} 4 \mathrm{xP}, \mathrm{y} 4 \mathrm{xO}, \mathrm{y} 4 \mathrm{xN}$, and $\mathrm{y} 4 \mathrm{xM}$ (Fig. 1). To determine if $\mathrm{y} 4 \mathrm{xP}$ can be induced by flavonoids, we performed semiquantitative reverse transcriptase (RT)PCR analysis using RNA isolated from rhizobia that were grown in the presence or absence of genistein, a potent inducer of nopX and other nod genes of $S$. fredii (Pueppke et al. 1998). For these experiments, we utilized USDA191, since it has only a single copy of $\mathrm{y} 4 \mathrm{xP}$. When primers designed to amplify the coding region of the $\mathrm{y} 4 \mathrm{xP}$ were utilized in the PCR reaction, a 1-kB RTPCR product was obtained from wild-type USDA191. Genistein

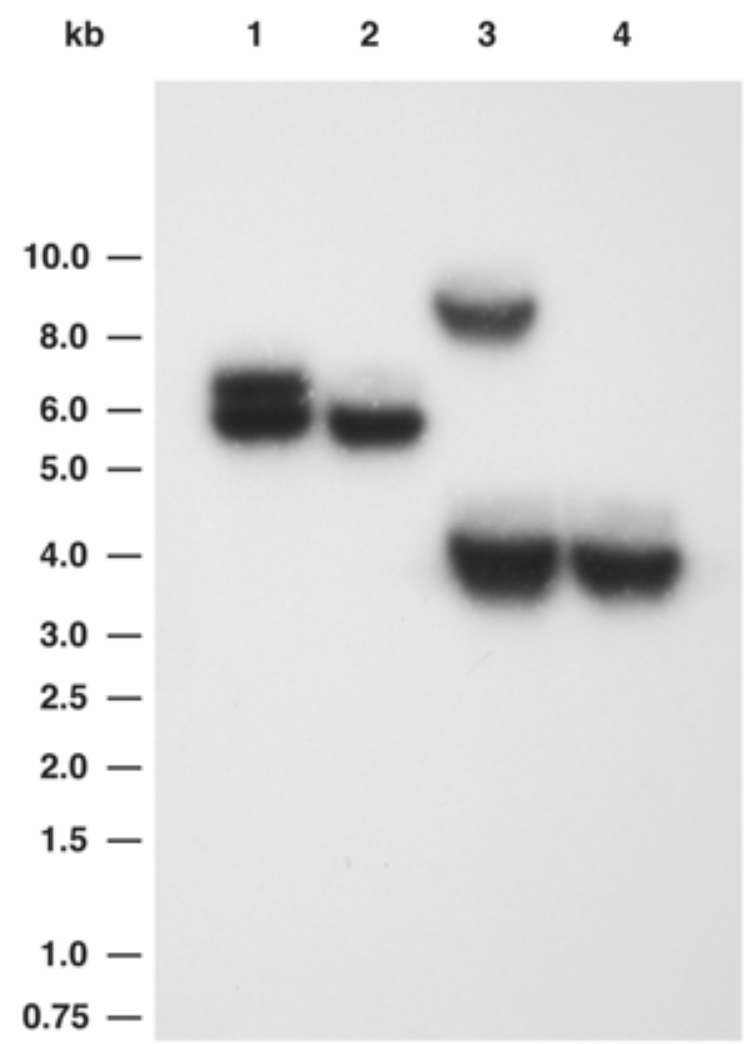

Fig. 2. Southern blot analysis of y4xP in Sinorhizobium fredii USDA257 and Sinorhizobium fredii USDA191. Genomic DNA from USDA257 (lanes 1 and 3) and USDA191 (lanes 2 and 4) were digested with HindIII (lanes 1 and 2) and SalI (lanes 3 and 4), respectively, and were separated on a $0.7 \%$ agarose gel. The gel was blotted onto nitrocellulose and probed with ${ }^{32} \mathrm{P}$ labeled $\mathrm{y} 4 \mathrm{xP}$ coding region. The numbers on the left indicate the positions and sizes of molecular weight marker. 
addition to the growth media clearly enhanced the $\mathrm{y} 4 \mathrm{xP}$ transcript levels (Fig. 6). No RT-PCR products were amplified from RNA isolated from the $\triangle \mathrm{y} 4 \mathrm{xP}$ deletion mutant. However, the production of the RT-PCR product was restored when the mutant was complemented with a plasmid copy of $y 4 x P$. As in the wild type, the accumulation of $\mathrm{y} 4 \mathrm{xP}$ transcript was severalfold greater in cells cultured in the presence of genistein (Fig. 6). To determine if deletion of $\mathrm{y} 4 \mathrm{yP}$ had any effect on TTSS, we monitored the transcription of flavonoid-inducible genes nopA, nopX, and nopL (Deakin et al. 2005; Krause et al. 2002; Krishnan et al. 2003). RT-PCR analysis revealed the accumulation of nopA, nopX, and nopL transcripts in the wild type, the $\triangle \mathrm{y} 4 \mathrm{xP}$ deletion mutant, and the complemented strain (Fig. 6). As in the case of $\mathrm{y} 4 \mathrm{xP}$, addition of genistein clearly enhanced the transcription of all these genes.

Since $\mathrm{y} 4 \mathrm{xP}$ transcription is inducible by flavonoids, we wanted to ascertain if cysteine synthase activity is also elevated in rhizobia grown in the presence of the nod-gene inducer. In our initial experiments, cysteine synthase activity was measured in USDA257 and USDA191 cells that were grown for $38 \mathrm{~h}$ in the absence or presence of genistein. Under such conditions, we were unable to detect any significant difference in the cysteine synthase activity between induced and noninduced cultures. Therefore, we monitored cysteine synthase activity at different timepoints after the addition of genistein. Clearly, genistein elevated cysteine synthase activity during the first $3 \mathrm{~h}$ of incubation after its addition. This difference was not seen when genistein was present in the culture longer than $6 \mathrm{~h}$ (Fig. 7).

\section{Symbiotic properties of nonpolar $\Delta y 4 x P$ mutants.}

We have earlier shown that mutations in the genes encoding the Nops and TTSS machinery extend the ability of USDA257 to nodulate 'McCall' soybean. To determine if USDA257 $\triangle \mathrm{y} 4 \mathrm{xP}$ mutant has a similar phenotype, we tested the ability of this mutant to form nodules on 'McCall' soybean. The $\Delta \mathrm{y} 4 \mathrm{xP}$ mutant failed to form nodules on 'McCall', indicating that $\mathrm{y} 4 \mathrm{xP}$ may not be involved in regulating soybean cultivar specificity. Interestingly, USDA191, a strain that does not exhibit

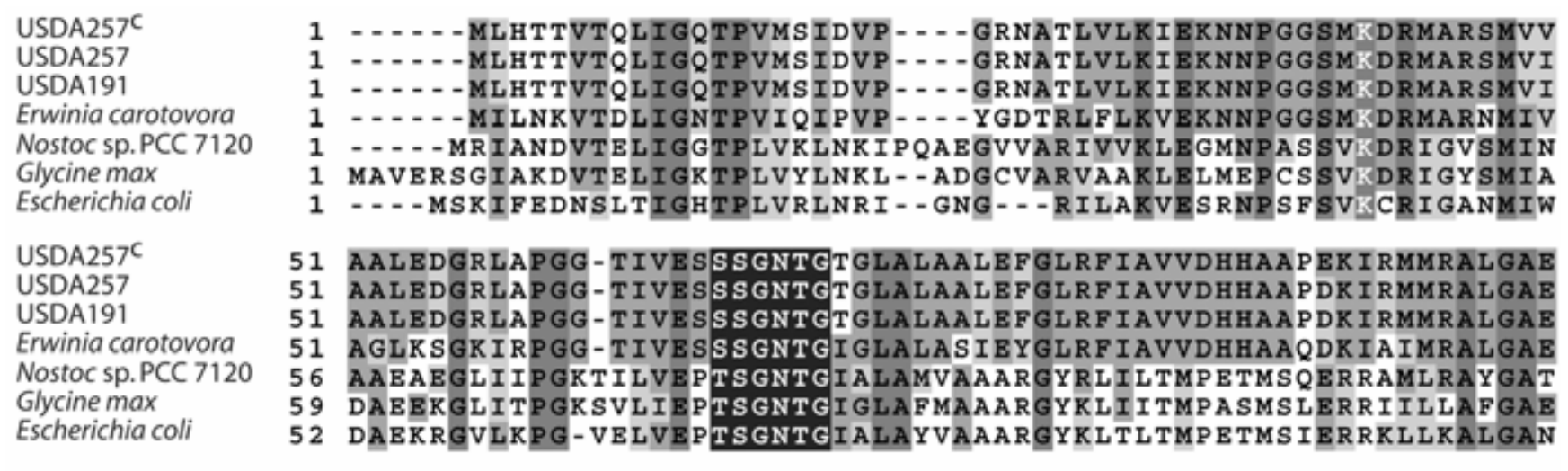

USDA257C

USDA257

USDA191

Erwinia carotovora

Nostoc sp. PCC 7120

Glycine max

Escherichia coli

110 IRYVEGDFRDDEVAVVERQRLAAQLGAQLPGALFMNQSDNPANPEG AG - LVDELVAQLP

110 IRYVEGDFREDEVAVVERQRLAAQLGAQLPGALFMNQSDNPANPAG TG-LVDELVAQLP

110 IRYVEGDFREDEVAVVERQRLAAQLGAQLPGALFMNQSDNPANPAG TG-LVDELVAQLP

110 IRYVSGDYGEDEVAVVERQRMAAQLAEEIPGAVFMNQSDNAANAGG AD - FVRELFSQIG

116 LELTPGTEGMRGAIRKAEEIVASTPDTH-- - MLQQFRNPANPKI RETTAEEIWNDTD

119 LVLTDPAKGMKGAVQKAEEILAKTPNAY - - - - ILQQFENPANPKV YETTGPEIWKGSD

111 LVLTEGAKGMKGAIQKAEEIVASNPEKYL- - - LLQQFSNPANPEI EKTTGPEIWEDTD

\begin{tabular}{|c|c|c|}
\hline $57 \mathrm{C}$ & 169 & GIDAFVGCVCICGSI \\
\hline & 169 & TGISQRVK- - RNNPAVRTIAVBPAGSIVFGKPG- - - HPYI \\
\hline & & RVK- - RNNPAVRTIAVEPAGSIVFGKPG- - - HPYY \\
\hline & 169 & CGSMTGISHGLK - - VHNPDIATIAVEPVGSIVFGHPG- \\
\hline & 171 & BPSNSPILSGG - \\
\hline & 174 & GI \\
\hline & & G L \\
\hline SL & 22 & - \\
\hline & 222 & YGCII \\
\hline & 222 & YGCI \\
\hline & 221 & YSCII \\
\hline & 223 & PDVLRLELVD \\
\hline & 226 & TAKLLALKEGL \\
\hline & & \\
\hline $7^{c}$ & 282 & $G-G B K$ \\
\hline & 282 & DG-GEK \\
\hline & 282 & TVVTTVADG-GEKYLGTI \\
\hline & 281 & DRIGGNVVLAIADG-GEKYLHTVFN \\
\hline & & IVMTOPSFGRRYL, \\
\hline & 285 & JAVFPSFGERYLS \\
\hline & & (e) \\
\hline
\end{tabular}

Fig. 3. Multiple alignment of the amino acid sequences of cysteine synthase. Dashes indicate gaps to facilitate best alignment. Dark gray shading indicates conserved residues; mid gray shading indicates residues showing more than $60 \%$ identity; light gray shading indicates those residues showing more than $60 \%$ similarity. The active site lysine (white on dark gray), the substrate loop (white on black), and residues that interact with pyridoxal phosphate (white on light gray) are indicated. 
soybean cultivar specificity was able to form more nodules on 'McCall' soybean. An examination of the kinetics of nodule formation revealed that the USDA191 $\Delta \mathrm{y} 4 \mathrm{xP}$ mutant derivative was more efficient in initiating nodules (Fig. 8). Twelve days after inoculation, the $\mathrm{y} 4 \mathrm{xP}$ mutant had twice the number of nodules than did the wild type. This difference in the ability to efficiently initiate nodules appears to be controlled by $\mathrm{y} 4 \mathrm{xP}$, since the complemented strain exhibited similar nodulation kinetics as the wild-type USDA191 (Fig. 8).

\section{A}

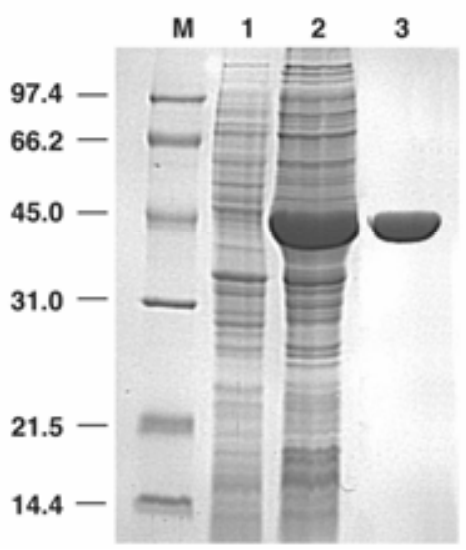

B

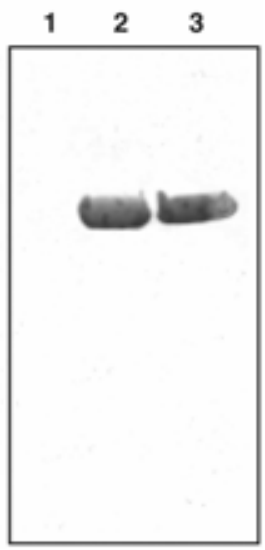

Fig. 4. Expression and purification of recombinant USDA257 Y4XP. The coding region of $\mathrm{y} 4 \mathrm{xP}$ was cloned in an expression vector $\mathrm{pET} 28 \mathrm{a}(+)$ and introduced into Escherichia coli ER2566. Recombinant protein expression was induced by the addition of $1 \mathrm{mM}$ isopropyl-beta-D-thiogalactoside (IPTG) to the culture media. Following overnight growth at $37^{\circ} \mathrm{C}$, the cells were harvested and the recombinant protein was purified on a nickel-affinity column. The proteins were fractioned in duplicate gels by $12.5 \%$ sodium dodecylsulphate polyacrylamide gel electrophoresis and were either A, stained with Coomassie brilliant blue or $\mathbf{B}$, transferred to a nitrocellulose membrane Western blot analysis. The blot was probed with antibodies raised against soybean cysteine synthase. Lane $\mathbf{M}$ : molecular weight markers; lane 1, protein from noninduced cultures; lane 2, protein from IPTGinduced cultures; and lane 3. purified recombinant Y4XP. The sizes of the molecular weight markers in kilodaltons are shown on the left margins of each figure.

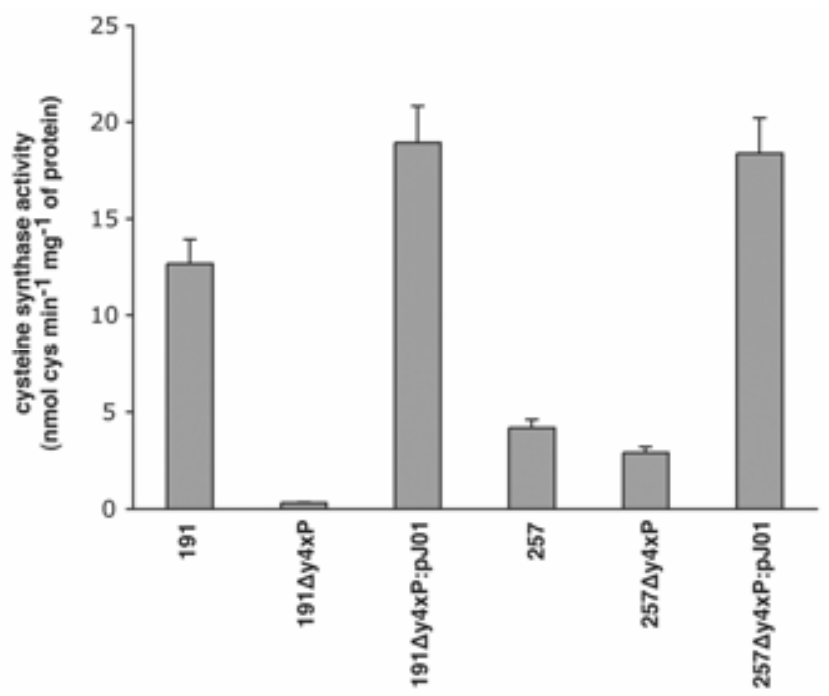

Fig. 5. Cysteine synthase activity in Sinorhizobium fredii. Crude cell-free protein extracts obtained from $\triangle \mathrm{y} 4 \mathrm{xP}$ deletion mutants, complemented strains, and the wild-type USDA257 and USDA191 were used to measure cysteine synthase activity. Cysteine synthase activity was measured by the conversion of $\mathrm{O}$-acetylserine into cysteine following spectrophotometric absorbance at $550 \mathrm{~nm}$.

\section{USDA191 $\Delta y 4 x P$ mutant shows subtle differences} in Nops production.

Previous studies have demonstrated that Nops are involved in either positively or negatively influencing nodulation in a host-dependent manner (Marie et al. 2001). Since the USDA191 $\triangle \mathrm{y} 4 \mathrm{xP}$ mutant forms a greater number of nodules on 'McCall' soybean than does the wild-type parent, we wanted to determine

A

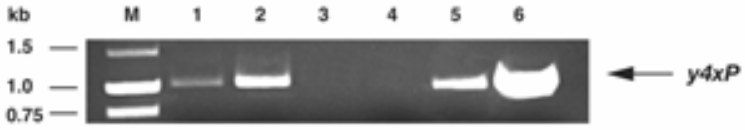

B

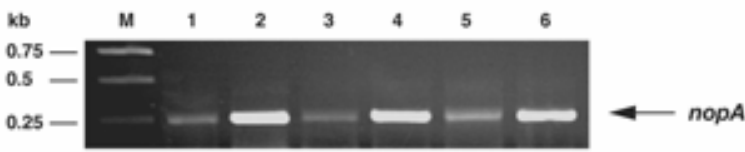

C

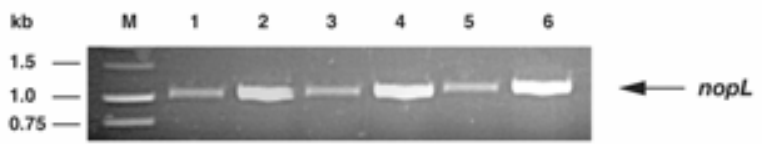

D

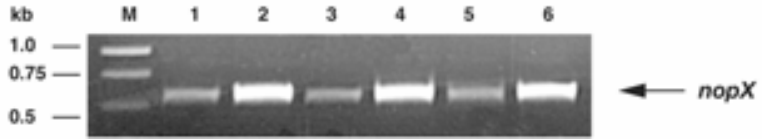

Fig. 6. Semiquantitative reverse transcriptase-polymerase chain reaction (RT-PCR) analysis of cysteine synthase mRNA in Sinorhizobium fredii USDA191. Total RNA isolated from USDA191 grown in the absence (lanes 1,3, and 5) or presence (lanes 2, 4, and 6) of $1 \mu \mathrm{M}$ genistein was used as a template for RT-PCR. The products obtained utilizing primers designed to amplify either the complete coding regions of $\mathbf{A}, \mathrm{y} 4 \mathrm{xP}, \mathbf{B}$, $n o p A$, and $\mathbf{C}$, nopL, or $\mathbf{D}$, a segment of the coding region of nopX are shown. Sizes of the molecular weight markers are indicated on the left side of the figure. Lanes 1 and 2, USDA191; lanes 3 and 4, USDA191 $\Delta y 4 x P$; lanes 5 and 6, USDA191 $\Delta \mathrm{y} 4 \mathrm{xP}(\mathrm{pJO1})$.

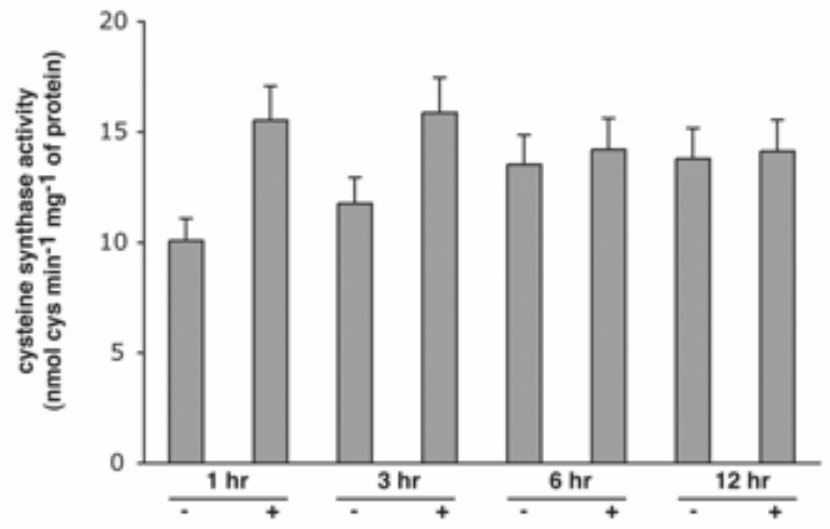

Fig. 7. Flavonoid induction transitionally increases cysteine synthase activity. USDA191 cells were harvested at different times after the addition of genistein, and cysteine synthase activity was measured from the crude cell-free extracts. Genistein was added when the culture reached an optical density of 0.5 (absorbance at $600 \mathrm{~nm}$ ), and samples were taken at $1,3,6$, and $12 \mathrm{~h}$ after induction. Cysteine synthase activity was measured by the conversion of $O$-acetylserine into cysteine following spectrophotometric absorbance at $550 \mathrm{~nm}$. 
if this phenotype is mediated through changes in Nops production. We isolated extracellular proteins from equal volumes of bacterial cultures that were grown in the presence of genistein. A comparison of proteins isolated from the wild type and the USDA191 $\Delta y 4 x P$ mutant revealed similar protein profiles (Fig. 9A). However, the $\mathrm{y} 4 \mathrm{xP}$ mutant contained a lesser amount of protein than the wild type. When equal amounts of protein were analyzed by SDS-PAGE, both USDA191 and the $\mathrm{y} 4 \mathrm{xP}$ mutant exhibited the same protein profiles (Fig. 9B). Western blot analysis using antibodies raised against NopX, NopB, and NopA confirmed that these proteins were present in lesser amounts in the $\mathrm{y} 4 \mathrm{xP}$ mutant (Fig. 9C).

\section{y4xP does not encode a protein}

of the TTSS nor is its product secreted.

Since $\mathrm{y} 4 \mathrm{xP}$ is located in the midst of the TTSS, we performed experiments to ascertain whether it encodes a component of the TTSS and whether the $\mathrm{y} 4 \mathrm{xP}$-encoded protein is secreted. Since the USDA191 y4xP mutant produces the same profile of TTSS proteins as the wild type (Fig. 9), it appears that $\mathrm{y} 4 \mathrm{xP}$ is not an integral part of the TTSS. The TTSS is highly conserved among symbionts, plant, and animal bacterial pathogens. In these bacteria, cysteine synthase has not been reported to be a component of the TTSS. To verify whether Y4XP is secreted, we purified extracellular proteins from genistein-induced cultures of USDA191 and assayed for the presence of cysteine synthase activity. We were unable to detect cysteine synthase activity in the extracellular protein fraction, while the activity was clearly seen in the protein extract from the cell pellet. Our observation indicates that Y4XP is not an extracellular protein.

\section{DISCUSSION}

In this study, we have shown that $\mathrm{y} 4 \mathrm{xP}$ codes for cysteine synthase. Several lines of evidence support our contention that $\mathrm{Y} 4 \mathrm{XP}$ is a cysteine synthase. A nonpolar $\triangle \mathrm{y} 4 \mathrm{xP}$ mutant revealed drastically reduced cysteine synthase activity. This reduction in cysteine synthase activity was completely restored when a plasmid containing $\mathrm{y} 4 \mathrm{xP}$ was introduced into this mutant. When the deduced amino acid sequence of $\mathrm{y} 4 \mathrm{xP}$ was compared with cysteine synthase primary structures representing both eukaryotic and prokaryotic sources, a significant homology was noted. Additionally, the active site lysine residue and

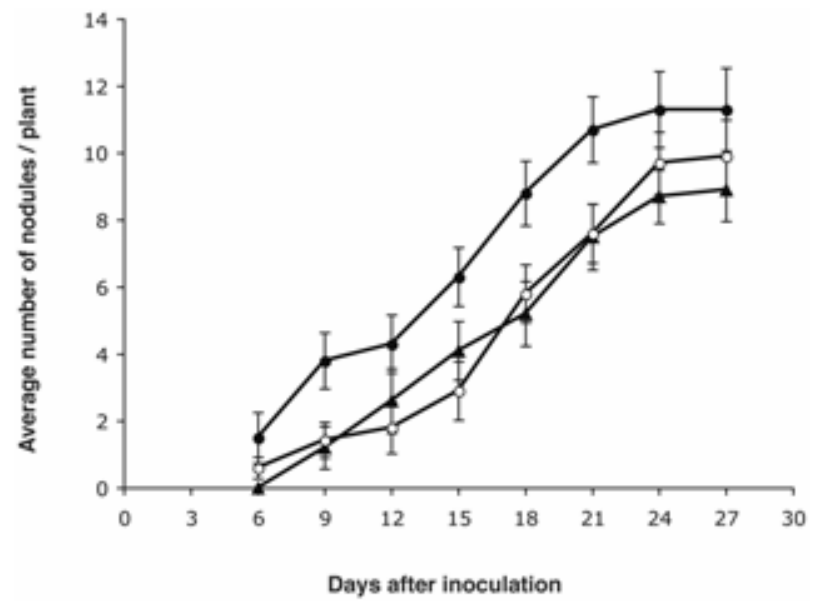

Fig. 8. Symbiotic properties of the $\triangle \mathrm{y} 4 \mathrm{xP}$ deletion mutant of USDA191. Seedlings of Glycine $\max$ cv. McCall were inoculated with either USDA191 (O----O), USDA191 $\Delta y 4 x P(\bullet---\bullet)$, or USDA191 $4 y 4 x P(p J O 1)(\mathbf{\Delta}-----\mathbf{A})$. Nodules were counted on day 6 after inoculation and on every third day thereafter until day 27. Results are from three independent experiments, using 10 plants per treatment in each case. other amino acids that putatively bind the pyridoxal phosphate cofactor are all conserved in Y4XP. Our attempts to demonstrate cysteine synthase activity with a recombinant Y4XP expressed in E. coli were not successful. The E. coli-expressed heterologous protein formed inclusion bodies, making isolation of nondenatured protein for enzymatic analysis difficult. However, we were able to demonstrate immunological relatedness of Y4XP to that of soybean cysteine synthase.

An examination of the genetic organization of the USDA257 TTSS locus revealed that six ORF (y4yB, y4yA, y4xP, y4xO, $\mathrm{y} 4 \mathrm{xN}$, and $\mathrm{y} 4 \mathrm{xM})$, some of which share overlapping start and stop codons, are found between two Nops-encoding genes, nopX and nopL. We have demonstrated that inactivation of NopX abolishes the transcription of $\mathrm{y} 4 \mathrm{yB}$ and $\mathrm{y} 4 \mathrm{yA}$, indicating that NopX and the two ORF may constitute a single transcriptional unit (Jiang and Krishnan 2000). A similar situation has been reported in NGR234 (Perret et al. 1999). In both USDA257 and NGR234, this operon was induced by flavonoids indicating that it may have a role in symbiosis. Inactivation of y4yB and y4yA, however, had no observable effect on the ability of USDA257 to nodulate soybean cultivar Peking (Jiang and Krishnan 2000). In this present study, we observed that inactivation of $\mathrm{y} 4 \mathrm{xP}$ in USDA191 slightly enhanced the ability of the bacteria to nodulate soybean cultivar McCall. It is not clear how cysteine synthase, a key enzyme in sulfur assimilation could lead to enhanced nodulation. One possibility is that the inactivation of $\mathrm{y} 4 \mathrm{xP}$ could have affected metabolism, resulting in alterations in symbiotic signals such as lipopolysaccharides and Nod factors. Since USDA257 and USDA191 do not contain sulfated Nod factors (Bec-Ferte et al. 1994, 1996), it is unlikely that the symbiotic phenotype of $\mathrm{y} 4 \mathrm{xP}$ mutants is mediated by altered Nod factors. Although the $\mathrm{y} 4 \mathrm{xP}$ mutant was created by the insertion of an $n p t I I$ cassette lacking the rho-independent transcriptional terminator, it is possible that this insertion had an unexpected effect on the transcription of genes located downstream of y4xP. However, RT-PCR analysis indicates that transcription of nopA, nopX, and nopL, a gene located downstream of $\mathrm{y} 4 \mathrm{xP}$, are not affected by inactivation of $\mathrm{y} 4 \mathrm{xP}$. Reduced Nops production by the $\Delta \mathrm{y} 4 \mathrm{xP}$ mutant is a more plausible explanation for the enhanced nodulation phenotype exhibited by this mutant. Altered Nops have been shown to either enhance, decrease, or have no effect on nodulation, in a host-dependent manner. We have demonstrated that NopX mutant of USDA257 can initiate nodules
A

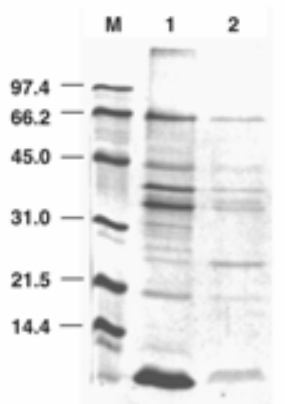

B

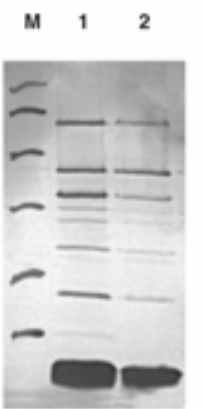

C

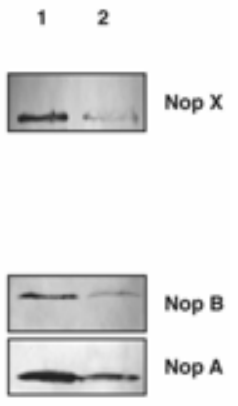

Fig. 9. Comparison of Nops production in USDA191 and USDA191 $\Delta y 4 x P$ mutant. Extracellular proteins from genistein-induced cultures of USDA191 (lane 1) and USDA191 $\Delta y 4 x P$ mutant (lane 2) were resolved by $15 \%$ sodium dodecylsulphate polyacrylamide gel electrophoresis and either $\mathbf{A}$ and $\mathbf{B}$, stained with Coomassie brilliant blue or $\mathbf{C}$, transferred to a nitrocellulose membrane for Western blot analysis. Blots of identical gels were immunostained with NopX, NopB, and NopA antibodies, respectively. Panel A shows the protein profile obtained from equal numbers of bacterial cells, while $B$ reveals the profile obtained when equal amounts of protein $(50 \mu \mathrm{g})$ was used. The sizes of the molecular weight markers in kilodaltons are indicated. 
on 'McCall' soybean while the wild-type parent is unable to do so (Meinhardt et al. 1993). In contrast, USDA191, which elaborates the same set of Nops as USDA257, albeit in different amounts when grown in the presence of flavonoids, is still able to nodulate 'McCall' soybean ( $\mathrm{H}$. B. Krishnan, unpublished observations; Krishnan and Pueppke 1993; Krishnan et al. 1995). Thus, it appears that soybean cultivar-specific nodulation may be mediated by the relative concentration of different Nops secreted by USDA257. A quantitative comparison of the Nops production by USDA191 and USDA257 is necessary to determine if a difference in Nops concentration contributes to host specificity.

USDA257 contains two copies of $\mathrm{y} 4 \mathrm{xP}$, one is localized on the sym plasmid while the other is contained within the bacterial chromosome. In contrast, USDA191 contains one copy of the gene, which is located on the sym plasmid. Similarly, y4yB and y4yA are also duplicated in the USDA257 genome (Jiang and Krishnan 2000). Recently, the occurrence of duplicated copies of $\mathrm{y} 4 \mathrm{yB}, \mathrm{y} 4 \mathrm{yA}, \mathrm{y} 4 \mathrm{xp}, \mathrm{y} 4 \mathrm{xO}, \mathrm{y} 4 \mathrm{xN}$, and $\mathrm{y} 4 \mathrm{xM}$ has been shown in NGR234 (Streit et al. 2004). One set of these genes is located on the sym plasmid (pNGR234a), which contains most of the symbiotic genes of this bacteria, and the second copy is on a megaplasmid (pNGR234b). In both USDA257 and NGR234, a copy of $y 4 y B, y 4 y A, y 4 x P, y 4 x O, y 4 x N$, and $y 4 x M$ is located in a region that contains genes encoding a functional TTSS (Krishnan et al. 2003; Viprey et al. 1998). This cluster of ORF does not appear to be directly involved in type III protein secretion, since mutation in three of the ORF (y4yA, y4yB, and $\mathrm{y} 4 \mathrm{xP}$ ) does not abolish the production and secretion of Nops (Jiang and Krishnan 2000; this study). Their presence in the midst of a functional TTSS of USDA257 indicates acquisition by horizontal gene transfer from other microbes. This contention is supported by the recent finding that some gene clusters located on pNGR234b were similar to those in other soil- and plant-associated microbes (Streit et al. 2004).

\section{MATERIALS AND METHODS}

\section{Bacterial strains and growth conditions.}

Bacterial strains and plasmids used in this study are listed in Table 1. USDA257 and USDA191 were maintained on yeast extract mannitol medium (Vincent 1970 ) at $30^{\circ} \mathrm{C}$. E. coli strains were grown in Luria-Bertani broth at $37^{\circ} \mathrm{C}$. When necessary, antibiotics were added to the medium at the following concentrations: tetracycline, $10 \mu \mathrm{g} / \mathrm{ml}$; kanamycin, $50 \mu \mathrm{g} / \mathrm{ml}$; ampicillin, $100 \mu \mathrm{g} / \mathrm{ml}$; spectinomycin, $50 \mu \mathrm{g} / \mathrm{ml}$; and gentamicin, $10 \mu \mathrm{g} / \mathrm{ml}$.

\section{Nucleic acid manipulation and analysis.}

Recombinant DNA techniques were performed according to standard protocols (Ausubel et al. 1991). Genomic DNA and total RNA were isolated from $S$. fredii as described (Kovacs et al. 1995). DNA sequence was determined with an Applied Biosystems 3730 DNA analyzer using Applied Biosystems Prism BigDye Terminator cycle sequencing chemistry (Applied Biosystems, Foster City, CA, U.S.A.). Polymerase chain reaction (PCR) was performed with Taq DNA polymerase according to the manufacturer's protocol. Radioactive hybridization probes were prepared using the random primer labeling kit (Takara Mirus Bio, Madison, WI, U.S.A.). Southern blotting and hybridizations were performed according to established protocols (Sambrook et al. 1989).

\section{Construction of the nonpolar $\Delta \mathbf{y} 4 \mathbf{x P}$ deletion mutant.}

Two 1-kb DNA regions flanking start and stop codons of the y4xP ORF were amplified by PCR utilizing pHBK447 as a template. The primers for the upstream region, $5^{\prime}$-cttccgcggtcg atgacgagccceggccttgtg-3' and 5'-gcagatatctgaccatttgcggcgctg gccgcaccgg- $3^{\prime}$, contained SacII and EcoRV restriction sites, while those for the downstream region, $5^{\prime}$-ctggtccaggatatcaacct ctccaattgtgtcgg-3' and 5'atcggtggactcgagggaagaactggagg-3', included EcoRV and XhoI sites to facilitate cloning. A nptII cassette minus the rho-independent transcriptional terminator was isolated from pCPP2988 (Alfano et al. 1996) and was inserted between the two PCR fragments, thus eliminating the $\mathrm{y} 4 \mathrm{xP}$ coding region. This DNA fragment was subsequently cloned into the SmaI site of pJQ200 mp18 (Quandt and Hynes 1993), resulting in pJO2. Utilizing triparental mating with helper plasmid pRK2013, this construct was mobilized into USDA257 and USDA191 (Figurski and Helinski 1979). Double recombination events were selected by plating bacteria on yeast extract medium containing 5\% (wt/vol) sucrose. Putative USDA257 $\Delta y 4 x P$ and USDA191 $\Delta y 4 x P$ mutants were confirmed by Southern blot analysis.

\section{Expression of $\mathrm{y} 4 \mathrm{xP}$ in $E$. coli.}

The coding region of USDA257 y4xP was amplified by PCR, using DNA from pHBK447 as a template. The $\mathrm{N}$ and $\mathrm{C}$

Table 1. Bacterial strains and plasmids used in this study

\begin{tabular}{|c|c|c|}
\hline Strain or plasmid & Relevant characteristics & Source or reference \\
\hline \multicolumn{3}{|l|}{ Strains } \\
\hline Sinorhizobium fredii USDA257 & Broad-host range, $\mathrm{Nod}^{+}$on soybean & Heron and Pueppke 1984 \\
\hline Sinorhizobium fredii USDA191 & Broad-host range, $\mathrm{Nod}^{+}$on soybean & Heron and Pueppke 1984 \\
\hline USDA $257 \triangle y 4 x P$ & USDA257 derivative in which y $4 \mathrm{xP}$ was replaced with $n p t \mathrm{II}, \mathrm{Km}^{\mathrm{r}}$ & This study \\
\hline USDA257 $\triangle \mathrm{y} 4 \mathrm{xP}:: \mathrm{pJO} 1$ & USDA257 $\Delta \mathrm{y} 4 \mathrm{xP}$ mutant carrying pJO1, $\mathrm{Km}^{\mathrm{r}}, \mathrm{Tc}^{\mathrm{r}}$ & This study \\
\hline USDA257 $4 \mathrm{y} 4 \mathrm{xP}:: \mathrm{pRF} 447$ & USDA257 $\Delta \mathrm{y} 4 \mathrm{xP}$ mutant carrying pRF447, $\mathrm{Km}^{\mathrm{r}}, \mathrm{Tc}^{\mathrm{r}}$ & This study \\
\hline USDA191 $\triangle \mathrm{y} 4 \mathrm{xP}$ & USDA191 derivative in which y4xP was replaced with $n p t I I, \mathrm{Km}^{\mathrm{r}}$ & This study \\
\hline USDA191 $\triangle \mathrm{y} 4 \mathrm{xP}:: \mathrm{pJO} 1$ & USDA191 $\Delta y 4 x P$ mutant carrying pJO1, $\mathrm{Km}^{\mathrm{r}}, \mathrm{Tc}^{\mathrm{r}}$ & This study \\
\hline USDA191 $\Delta y 4 x P:: p R F 447$ & USDA191 $\Delta \mathrm{y} 4 \mathrm{xP}$ mutant carrying pRF447, $\mathrm{Km}^{\mathrm{r}}, \mathrm{Tc}^{\mathrm{r}}$ & This study \\
\hline DH5 $\alpha$ & $\phi 80$ lacZ $\Delta \mathrm{M} 15 \Delta($ lacZYA-argF) U169 hsdR17 recA1 endA1 thi-1 & Gibco BRL \\
\hline \multicolumn{3}{|c|}{ P } \\
\hline pGEM-T Easy & PCR cloning vector, $A p^{r}$ & Promega \\
\hline pBSKSII & Cloning vector, $\mathrm{Ap}^{\mathrm{r}}$ & Stratagene \\
\hline pHBK447 & pLAFR1 cosmid carrying TTSS genes from USDA257, $\mathrm{Tc}^{\mathrm{r}}$ & Krishnan et al. 2003 \\
\hline pRK2013 & incPl helper plasmid, $\mathrm{Km}^{\mathrm{r}}$ & Figurski and Helinski 1979 \\
\hline pCPP2988 & $\begin{array}{l}\text { pBluescript II KS vector carrying } 1.5-\mathrm{kb} \text { HindIII and SalI fragment from pRZ102 with } \\
\text { nptII lacking terminator }\end{array}$ & Alfano et al. 1996 \\
\hline pJQ200mp18 & Suicide vector for gene replacement, $\mathrm{Gm}^{\mathrm{r}}$ & Quandt and Hynes 1993 \\
\hline pRK415 & Broad-host-range vector, $\mathrm{Tc}^{\mathrm{r}}$ & Keen et al. 1988 \\
\hline pJ01 & $\mathrm{y} 4 \mathrm{xP}$ coding region cloned in $\mathrm{pRK} 415, \mathrm{Tc}^{\mathrm{r}}$ & This study \\
\hline pJ02 & pJQ200mp18 carrying 3.49-kb insert containing $\Delta y 4 \mathrm{xP}:: n p t I I, \mathrm{Km}^{\mathrm{r}}, \mathrm{Gm}^{\mathrm{r}}$ & This study \\
\hline
\end{tabular}


terminal-specific primers were 5'-CCAACATATGATGCTG CACACGACCGTAAC-3' and 5'-GGTTCTCGAGTCATGCT GCCCGCGCCTTTC-3', which contained a NdeI and XhoI restriction site, respectively, to facilitate subsequent cloning into E. coli expression vector pET28(a)+ (Calbiochem-Novabiochem, San Diego, CA. U.S.A.). The resultant recombinant plasmid was introduced into E. coli ER2566 (New England Biolabs, Beverly, MA, U.S.A.). Bacterial cells transformed with the recombinant plasmid were grown at $37^{\circ} \mathrm{C}$ in Luria broth medium. When the culture reached optical density at 600 $\mathrm{nm}\left(\mathrm{OD}_{600}\right)$ of 0.9 (absorbance at $\left.600 \mathrm{~nm}\right)$, IPTG was added to a final concentration of $1 \mathrm{mM}$ and growth was allowed to continue overnight. Recombinant protein was purified by affinity chromatography under denaturing conditions using a Ni-NTA agarose column following the manufacture's protocol (Qiagen, Valencia, CA, U.S.A.).

\section{Electrophoresis and Western blot analysis.}

Extracelluar proteins were isolated from $S$. fredii grown in the presence or absence of $1 \mu \mathrm{M}$ genistein as described by Krishnan and associates (2003). Bacterial proteins were resolved by SDS-PAGE, using the discontinuous buffer system of Laemmli (1970). Protein samples in SDS sample buffer (2\% SDS, $60 \mathrm{mM}$ Tris- $\mathrm{HCl}$ (pH 6.8), 5\% $\beta$-mercaptoethanol) were boiled for $5 \mathrm{~min}$ at $100^{\circ} \mathrm{C}$ before commencement of electrophoresis. The resolving gels $(10 \times 8 \times 0.75 \mathrm{~cm})$ contained $15 \%$ acrylamide and the stacking gel $5 \%$ acrylamide. Electrophoresis was conducted at a constant current of $20 \mathrm{~mA}$ per slab for 1 $\mathrm{h}$ or until the tracking dye reached the bottom of the gel. Proteins were visualized by staining with Coomassie brilliant blue (Sigma-Aldrich, St. Louis). For Western blot analysis, proteins separated by SDS-PAGE were electroblotted onto nitrocellulose as described (Burnett 1981). NopX, NopB, and NopA antibodies were diluted 1:3,000 in TBS (Tris- $\mathrm{HCl} 10 \mathrm{mM}, \mathrm{pH}$ $7.5, \mathrm{NaCl} 500 \mathrm{mM}$ ) containing 5\% (wt/vol) nonfat dried milk. Immunoreactive polypeptides were detected employing the horseradish peroxidase color-development protocol provided by the manufacturer (Bio-Rad Laboratories, Inc., Richmond, CA, U.S.A.).

\section{RT-PCR analysis.}

Duplicate sets of $S$. fredii USDA191, $\Delta y 4 x P$ deletion mutants, and complemented derivatives were incubated on a rotary shaker at $30^{\circ} \mathrm{C}$ in liquid yeast mannitol extract (YEM) medium. When the cultures reached an $\mathrm{OD}_{600}$ of 0.5 , genistein at a final concentration of $1 \mu \mathrm{m}$ was added to one of the sets and were grown for an additional hour. Cells were harvested and RNA was prepared following the general procedure (Sambrook et al. 1989). The RNA was treated with DNaseI (Invitrogen, Carlsbad, CA, U.S.A.) to eliminate any contaminating DNA. The primer set combination used for amplification are as follows: $\mathrm{y} 4 \mathrm{xP}$ (forward primer: 5'-CCAACATATGATGCTGCACACGACCGTAA C-3'; reverse primer: 5'-GGTTCTCGAGTCATGCTGCCCGCG CCTTTC-3'), nopA (forward primer: 5'-ATGTCTAAAATAGG TACTGTCACGAG-3'; reverse primer: 5'-CTGTACGCGTTCA TCCGCCGCCTTC-3'), nopL (forward primer: 5'-ATGGATAT CAATTCAACCCGCCCACTAAAC-3'; reverse primer: 5'-TCA AATGTCAAAATCCAGCGATGGCCTG-3'), and nopX (forward primer: $5^{\prime}$-ATGTCGGCCAGCAACCTTTTACCAATGAT C-3'; reverse primer: 5'-GCCTCCACAGCGACCATCGCCCTG CGAGC-3'). RT-PCR was carried out in a final volume of $50 \mu \mathrm{l}$ using the One Step RT-PCR kit (Qiagen, Valencia, CA, U.S.A.). The thermal cycler program was $50^{\circ} \mathrm{C}$ for $30 \mathrm{~min}, 95^{\circ} \mathrm{C}$ for 15 min, 26 cycles at $94^{\circ} \mathrm{C}(1 \mathrm{~min})$, and $72^{\circ} \mathrm{C}(1 \mathrm{~min})$, followed by a final cycle of $10 \mathrm{~min}$ at $72^{\circ} \mathrm{C}$. After electrophoretic separation on a $0.8 \%(\mathrm{wt} / \mathrm{vol})$ agarose gel, an image of the resolved RTPCR products was recorded (LabRepco, Horsham, PA, U.S.A.).
Cysteine synthase assays.

USDA 257, USDA191, $\Delta y 4 x \mathrm{x}$ deletion mutants, and the complemented strains were grown in liquid YEM media in the presence or absence of $1 \mu \mathrm{M}$ genistein. Cells were pelleted by centrifugation and were resuspended in extraction buffer (100 $\mathrm{mM}$ Tris-HCl, $\mathrm{pH} 8.0,100 \mathrm{mM} \mathrm{KCl}, 20 \mathrm{mM} \mathrm{MgCl}_{2}, 1 \%$ Tween 80 , and $10 \mathrm{mM}$ dithiothreitol [DTT]). The slurry was sonicated twice for $90 \mathrm{~s}$ at $4^{\circ} \mathrm{C}$, and the cell debris was removed by centrifugation. Cysteine synthase activity in the supernatant was measured in a total volume of $200 \mu$ l containing $5 \mathrm{mM} O$-acetylserine (OAS), $3 \mathrm{mM}$ sodium sulphide, $10 \mathrm{mM}$ DTT, and $100 \mathrm{mM}$ sodium phosphate, $\mathrm{pH} 8.0$ (Warrilow and Hawkesford 1998). The reaction was initiated by the addition of OAS and was incubated at $26^{\circ} \mathrm{C}$ for $10 \mathrm{~min}$ prior to spectrophotometric analysis at $550 \mathrm{~nm}$. One unit of cysteine synthase activity is defined as the conversion of $1 \mathrm{mM}$ of OAS into cysteine per minute. Protein concentration in the cell extracts was determined with a Bio-Rad protein assay kit using bovine serum albumin as the standard.

\section{Plant nodulation assays.}

Surface-sterilized soybean seeds were germinated on $1 \%$ water-agar at $30^{\circ} \mathrm{C}$ for three days. Seedlings were first inoculated by immersing the roots in bacterial cultures of known density and were placed into sterile pouches premoistened with nitrogen-free water. Plants were placed in a growth chamber at a constant temperature of $28^{\circ} \mathrm{C}$, with light intensity of $500 \mu \mathrm{E} \mathrm{m}^{-2} \mathrm{~s}^{-1}$ under a 12-h day and night cycle. Nodulation responses were assessed visually, and nodules were counted every three days beginning six days after inoculation.

\section{Nucleotide sequence accession number.}

The nucleotide sequence of the chromosomal copy of USDA257 $\mathrm{y} 4 \mathrm{xP}^{\mathrm{c}}$ and USDA191 $\mathrm{y} 4 \mathrm{xP}$ are deposited in the GenBank database under accession number DQ008443 and DQ008444, respectively.

\section{ACKNOWLEDGMENTS}

We would like to thank J. Bennett and P. Beuselinck for critical review of this manuscript. Names are necessary to report factually on available data; however, neither the University of Missouri nor the United States Department of Agriculture (USDA) guarantees or warrants the standard of product and the use of the name by the University of Missouri or USDA implies no approval of the product to the exclusion of others that may be suitable.

\section{LITERATURE CITED}

Alfano, J. R., Bauer, D. W., Milos, T. M., and Collmer, A. 1996. Analysis of the role of the Pseudomonas syringae pv. syringae HrpZ harpin in elicitation of the hypersensitive response in tobacco using functionally non-polar hrpZ deletion mutations, truncated HrpZ fragments, and hrmA mutations. Mol. Microbiol. 19:715-728.

Annapurna, K., and Krishnan, H. B. 2003. Molecular aspects of soybean cultivar-specific nodulation by Sinorhizobium fredii USDA257. Indian J. Exp. Biol. 41:1114-1123.

Ausubel, F. M., Brent, R., Kingston, R. E., Moore, D. D., Seidman, J. G., and Smith, J. A. 1991. Current protocols in molecular biology. John Wiley \& Sons, New York.

Bec-Ferte, M. P., Krishnan, H. B., Prome, D., Savagnac, A., Pueppke, S. G., and Prome, J. C. 1994. Structures of nodulation factors from the nitrogen-fixing soybean symbiont Rhizobium fredii USDA257. Biochemistry 33:11782-11788.

Bec-Ferte, M. P., Krishnan, H. B., Savagnac, A., Pueppke, S. G., and Prome, J. C. 1996. Rhizobium fredii synthesizes an array of lipooligosaccharides, including a novel compound with glucose inserted into the backbone of the molecule. FEBS (Fed. Eur. Biochem. Soc.) Letters 393:273-279.

Bellato, C., Krishnan, H. B., Cubo, T., Temprano, F., and Pueppke, S. G. 1997. The soybean cultivar specificity gene nolX is present, expressed in a nodD-dependent manner, and of symbiotic significance in cultivar- 
nonspecific strains of Rhizobium (Sinorhizobium) fredii. Microbiology 143:1381-1388.

Broughton, W. J., Jabbouri, S., and Perret, X. 2000. Keys to symbiotic harmony. J. Bacteriol. 182:5641-5652.

Burnett, W. N. 1981. Western blotting: Electrophoretic transfer of proteins from SDS-polyacrylamide gels to unmodified nitrocellulose and radiographic detection with antibody and radioiodinated protein-A. Anal. Biochem. 112:195-203.

Chronis, D., and Krishnan, H. B. 2003. Sulfur assimilation in soybean: Molecular cloning and characterization of $O$-acetylserine (thiol) lyase (cysteine synthase). Crop Sci. 43:1819-1827.

Deakin, W. J., Marie, C., Saad, M. M., Krishnan, H. B., and Broughton, W. J. 2005. NopA is associated with cell surface appendages produced by the type III secretion system of Rhizobium sp. strain NGR234. Mol. Plant-Microbe Interact. 18:499-507.

Dénarié, J., Debellé, F., Truchet, G., and Promé, J. C. 1993. Rhizobium and legume nodulation: A molecular dialogue. Pages 19-30 in: New Horizons in Nitrogen Fixation. R. Palacios, J. Moira and W. E. Newton, eds. Kluwer, Dordrecht, The Netherlands.

Dénarié, J., Debellé, F., and Promé, J. C. 1996. Rhizobium lipochitooligosaccharide nodulation factors: Signaling molecules mediating recognition and morphogenesis. Ann. Rev. Biochem. 65:503-535.

Figurski, D. H., and Helinski, D. R. 1979. Replication of an origin-containing derivative of plasmid RK2 dependent on a plasmid function provided in trans. Proc. Natl. Acad. Sci. U.S.A. 76:1648-1652.

Heron, D. S., and Pueppke, S. G. 1984. Mode of infection, nodulation specificity, and indigenous plasmids of 11 fast-growing Rhizobium japonicum strains. J. Bacteriol. 160:1061-1066.

Heron, D. S., Ersek, T., Krishnan, H. B., and Pueppke, S. 1989. Nodulation mutants of Rhizobium fredii USDA257. Mol. Plant-Microbe Interact. 2:4-10

Jiang, G., and Krishnan, H. B. 2000. Sinorhizobium fredii USDA257, a cultivar-specific soybean symbiont, carries two copies of y4yA and $\mathrm{y} 4 \mathrm{yB}$, two open reading frames that are located in a region that encodes the type III protein secretion system. Mol. Plant-Microbe. Interact. 13:1010-1014.

Keen, N. T., Tamaki, S., Kobayasi, D., and Trollinger, D. 1988. Improved broad host-range plasmids for DNA cloning in gram-negative bacteria. Gene 70:191-197.

Keyser, H. H., Bohlool, B. B., Hu, T. S., and Weber, D. F. 1982. Fast growing rhizobia isolated from root nodules of soybean. Science 215:16311632.

Kovacs, L. G., Balatti, P. A., Krishnan, H. B., and Pueppke, S. G. 1995. Transcriptional organization and expression of nolXWBTUV, a locus that regulates cultivar-specific nodulation of soybean by Rhizobium fredii USDA257. Mol. Microbiol. 17:923-933.

Krause, A., Doerfel, A., and Göttfert, M. 2002. Mutational and transcriptional analysis of the type III secretion systems of Bradyrhizobium japonicum. Mol. Plant-Microbe Interact. 15:1228-1235.

Krishnan, H. B., and Pueppke, S. G. 1993. Flavonoid inducers of nodulation genes stimulate Rhizobium fredii USDA257 to export proteins into the environment. Mol. Plant-Microbe Interact. 6:107-113.

Krishnan, H. B., Kuo, C. I., and Pueppke, S. G. 1995. Elaboration of flavonoid-induced proteins by the nitrogen-fixing symbiont Rhizobium fredii is regulated by both nodD1 and nodD2, and is dependent on the cultivar specificity locus, nolXWBTUV. Microbiology 141:2245-2251.
Krishnan, H. B., Lorio, J., Kim, W. S., Jiang, G., Kim, K. Y., DeBoer, M and Pueppke, S. G. 2003. Extracellular proteins involved in soybean cultivar-specific nodulation are associated with pilus-like surface appendages and exported by a type III protein secretion system in $\mathrm{Si}$ norhizobium fredii USDA257. Mol. Plant-Microbe Interact. 16:617625.

Laemmli, U. K. 1970. Cleavage of structural proteins during the assembly of the head of bacteriophage T4. Nature 227:680-685.

Lodwig, E. M., Hosie, A. H. F., Bourdes, A., Findlay, K., Allaway, D., Karunakaran, R., Downie, J. A., and Poole, P. S. 2003. Amino-acid cycling drives nitrogen fixation in the legume-Rhizobium symbiosis. Nature 422:722-726.

Long, S.R. 1996. Rhizobium symbiosis: Nod factors in perspective. Plant Cell 8:1885-1898.

Marie, C., Broughton, W. J., and Deakin, W. J. 2001. Rhizobium type III secretion systems: Legume charmers or alarmers? Curr. Opin. Plant Biol. 4:336-342.

Meinhardt, L. W., Krishnan, H. B., Balatti, P. A., and Pueppke, S. G. 1993. Molecular cloning and characterization of a sym plasmid locus that regulates cultivar-specific nodulation of soybean by Rhizobium fredil USDA257. Mol. Microbiol. 9:17-29.

Patriarca, E. J., Tate, R., and Iaccarino, M. 2002. Key role of bacterial $\mathrm{NH}_{4}{ }^{+}$metabolism in Rhizobium-plant symbiosis. Microbiol. Mol. Biol. Rev. 66:203-222.

Perret, X., Freiberg, C., Rosenthal, A., Broughton, W. J., and Fellay, R. 1999. High-resolution transcriptional analysis of the symbiotic plasmid of Rhizobium sp. NGR234. Mol. Microbiol. 32:415-425.

Pueppke, S. G., Bolanos-Vasquez, M. C., Werner, D., Bec-Ferte, M. P., Prome, J. C., and Krishnan, H. B. 1998. Release of flavonoids by the soybean cultivar McCall and Peking and their perception as signals by the nitrogen-fixing symbiont Sinorhizobium fredii. Plant. Physiol. 117:599-608.

Pueppke, S. G., and Broughton, W. J. 1999. Rhizobium sp. strain NGR234 and $R$. fredii USDA257 share exceptionally broad, nested host ranges. Mol. Plant-Microbe Interact. 12:293-318.

Quandt, J., and Hynes, M. F. 1993. Versatile suicide vectors which allow direct selection for gene replacement in gram-negative bacteria. Gene 127:15-21.

Sambrook, J., Fritsch, E. F., and Maniatis, T. 1989. Molecular Cloning: A Laboratory Manual, 2nd ed. Cold Spring Harbor Press, Cold Spring Harbor, NY, U.S.A.

Schlaman, H. R. M., Okker, R. J. H., and Lugtenberg, B. J. J. 1992. Regulation of nodulation gene expression by NodD in rhizobia. J. Bacteriol. 174:5177-5182.

Streit, W. R., Schmitz, Perret, R. A., X., Staehelin, C., Deakin, W. J., Raasch, C., Liesegang, H., and Broughton, W. J. 2004. An evolutionary hot spot: The pNGR234b replicon of Rhizobium sp. strain NGR234. J. Bacteriol. 186:535-542.

Vincent, J. M. 1970. A manual for the practical study of root-nodule bacteria. Blackwell Scientific Publications, Oxford.

Viprey, V., Del Greco, A., Golinowski, W., Broughton, W. J., and Perret, X. 1998. Symbiotic implications of type III protein secretion machinery in Rhizobium. Mol. Microbiol. 28:1381-1389.

Warrilow, A. G. S., and Hawkesford, M. J. 1998. Separation, subcellular location and influence of sulfur nutrition on isoforms of cysteine synthase in spinach. J. Exp. Bot. 49:1625-1636. 